\title{
PENGARUH PEMBERIAN FISIOTERAPI DADA DAN PURSED LIPS BREATHING (TIUPAN LIDAH) TERHADAP BERSIHAN JALAN NAFAS PADA ANAK BALITA DENGAN PNEUMONIA
}

\author{
Titin Hidayatin \\ Program Studi Sarjana Keperawatan STIKes Indramayu \\ korespondensi : tienhidayatin85@gmail.com
}

\section{ABSTRAK}

Pneumonia adalah infeksi parenkim paru yang sering berdampak terhadap status oksigenasi terutama bersihan jalan napas. Tujuan dari penelitian ini adalah diketahuinya pengaruh pemberian fisioterapi dada dan pursed lips breathing terhadap bersihan jalan napas pada anak balita dengan pneumonia di RSUD Kabupaten Indramayu. Penelitian ini menggunakan menggunakan quasy experimental dengan rancangan non randomized without control group pretest-posttest dengan jumlah sampel yang akan diambil sebanyak 30 responden yang dibagi dalam 3 kelompok intervensi. Teknik pengambilan data adalah concecutive sampling. Hasil penelitian menunjukkan untuk kelompok fisioterapi dada serta kelompok fisioterapi dada dan pursed lips breathing menunjukkan ada pengaruh yang signifikan terhadap bersihan jalan napas dengan nilai $\mathrm{P}$ value 0,000 , sedangkan untuk kelompok pursed lips breathing tidak ada pengaruh terhadap bersihan jalan napas dengan nilai $\mathrm{P}$ value 0,112 . Hasil penelitian ini dapat dijadikan landasan dalam memberikan asuhan keperawatan mandiri pada anak balita yang mengalami pneumonia dengan bersihan jalan nafas.

Kata kunci : Pneumonia, balita, fisioterapi dada, pursed lips breathing.

\section{PENDAHULUAN}

Menurut WHO (2016) pneumonia merupakan pembunuh utama balita di dunia, lebih banyak dibandingkan dengan penyakit AIDS, malaria dan campak. Pneumonia disebut juga sebagai "pandemic yang terlupakan" atau "the forgotten pandemic", karena tidak banyak perhatian terhadap penyakit ini, sehingga pneumonia disebut juga pembunuh balita yang terlupakan atau "the forgotten killer of children". Kemenkes RI, (2016) menyebutkan bahwa hasil Sample Registration System (SRS) di Indonesia tahun 2014 pneumonia merupakan penyebab kematian nomor 3 pada balita, dengan angka cakupan berkisar antara $20-30 \%$, sedangkan pada tahun 2015 terjadi peningkatan menjadi 63,45\%. Data Kemenkes RI, (2016) menyatakan bahwa Jawa Barat termasuk dalam 10 besar dengan jumlah kasus pneumonia terbanyak yaitu $4,62 \%$.

Berdasarkan data Rekam Medik dan Registrasi pasien ruang perawatan anak RSUD Kabupaten Indramayu, didapatkan data pada tahun 2016 sebanyak 3.687 anak, sedangkan kasus pneumonia pada balita adalah 232 pasien dan data 2 bulan terakhir yaitu bulan Januari dan Februari 2017 jumlah kasus pneumonia pada anak balita adalah sebanyak 45 kasus dengan rincian 20 kasus pada bulan Januari dan 25 kasus pada bulan Februari 2017.

Masalah yang sering muncul pada balita dengan pneumonia yang dirawat di rumah sakit adalah distress pernafasan yang ditandai dengan nafas cepas, retraksi interkostal, pernafasan cuping hidung dan disertai dengan stridor (WHO, 2009). Distress pernafasan merupakan kompensasi tubuh terhadap kekurangan oksigen, karena konsentrasi oksigen yang rendah, akan menstimulus syaraf pusat untuk meningkatkan frekuensi pernafasan. Penurunan konsentrasi oksigen ke jaringan sering karena adanya obstruksi atau hambatan suplai oksigen ke jaringan. Pada umumnya faktor penyebab obstruksi jalan nafas atas dan bawah pada balita dengan pneumonia adalah karena peningkatan sekret sebagai salah satu manifestasi klinis adanya inflamasi pada saluran nafas (Wong, 2009).

Proses inflamasi dari penyakit pneumonia mengakibatkan produksi sekret meningkat sampai menimbulkan manifestasi klinis yang ada, sehingga muncul masalah 
ketidakefektifan bersihan jalan nafas. Ketidakefektifan bersihan jalan nafas merupakan keadaan dimana individu tidak mampu mengeluarkan sekret dari saluran nafas untuk mempetahankan jalan nafas dengan karakteristik dari ketidakefektifan bersihan jalan nafas adalah batuk, dispnea, gelisah, suara nafas abnormal (ronchi), perubahan frekuensi nafas, penggunaan otot bantu nafas, pernafasan cuping hidung dan sputum dalam jumlah berlebihan (Herdman, 2015).

Beberapa tindakan yang efektif untuk mengatasi ketidakefektifan bersihan jalan nafas adalah dengan fisioterapi dada (chest physiotherapy/CPT).. Terapi CPT termasuk postural drainage, perkusi dan vibrasi (Potter \& Perry, 2009). Fisioterapi dada sangat berguna bagi balita dengan penyakit paru baik yang bersifat akut maupun kronis, sangat efektif dalam upaya mengeluarkan sekret. Jadi tujuan pokok dari fisioterapi pada penyakit paru adalah mengembalikan dan memelihara fungsi otot - otot pernafasan dan membantu membersihkan sekret dari bronkhus dan untuk mencegah penumpukan sekret.

Intervensi lain yang dapat digunakan untuk mengatasi masalah ketidakefektifan bersihan jalan nafas selain CPT pada balita yaitu dengan teknik pursed lips breathing (PLB). PLB dapat meningkatkan ekspansi alveolus pada setiap lobus paru, sehingga tekanan alveolus meningkat dan dapat membantu mendorong sekret pada jalan napas saat ekspirasi dan dapat menginduksi pola napas menjadi normal (Brunner \& Sudarth, 2002).

Berdasarkan hal tersebut diatas peneliti tertarik untuk melakukan penelitian tentang pengaruh pemberian fisioterapi dada dan pursed lips breathing (tiupan lidah) terhadap bersihan jalan napas pada anak balita dengan pneumonia di RSUD Kabupaten Indramayu.

\section{METODE PENELITIAN}

Penelitian ini merupakan penelitian kuantitatif dengan desain penelitian Quasy Experimental pre-post test. Rancangan penelitian yang digunakan dalam penelitian ini adalah non equivalent without control group (non randomized without control group pretest-posttest) dengan memberikan pengukuran bersihan jalan napas (frekuensi nafas, bunyi nafas, irama nafas, dan penggunaan otot bantu pernafasan) sebelum dan sesudah dilakukan tindakan. Populasi yang digunakan dalam penelitian ini adalah anak balita dengan pneumonia yang dirawat. Sampel yang digunakan sebanyak 30 responden yang dibagi dalam 3 kelompok intervensi. Teknik pengambilan sampel yang digunakan adalah purposive sampling. Penelitian ini dilaksanakan di ruang golek RSUD Kabupaten Indramayu pada bulan Mei - Juli 2017. Analisis data yang digunakan adalah Cochran Post Hoc Mc Namer.

\section{HASIL PENELITIAN}

\section{Analisis Uji Univariat}

Hasil analisis karakteristik responden pada penelitian ini menggambarkan usia responden .

Tabel 1

Distribusi Karakteristik Responden Berdasarkan Umur ( $n=30)$

\begin{tabular}{lllll}
\hline \multicolumn{1}{c}{ Variabel } & Mean & Median & SD & $\begin{array}{c}\text { Minimal - } \\
\text { Maksimal }\end{array}$ \\
\hline Umur Responden & & & & \\
\hline 1. Fisioterapi dada & 2.50 & 2.00 & 1.269 & $1-5$ tahun \\
2. PLB & 2.60 & 2.50 & 1.174 & $1-4$ tahun \\
3. Fisioterapi dada \& & 2.60 & 2.50 & 0.699 & 1.4 tahun \\
& & & & \\
\hline
\end{tabular}




\section{Analisis Uji Bivariat}

1) Fisioterapi Dada

Tabel 2 Analisis Efektifitas Fisioterapi Dada Terhadap Bersihan Jalan Nafas pada Anak Balita dengan Pneumonia

\begin{tabular}{llccr}
\hline \multirow{2}{*}{ No } & $\begin{array}{c}\text { Pengukuran Bersihan Jalan Nafas } \\
\text { pada kelompok yang diberi } \\
\text { Fisiotherapi dada }\end{array}$ & \multicolumn{2}{c}{ Bersihan Jalan Nafas } & \multirow{2}{*}{ P } \\
\cline { 3 - 4 } & \multicolumn{2}{c}{ Tdk Bersih } & Bersih & Value \\
\hline 1 & Sebelum intervensi 1 pagi (hari 1) & $10(100 \%)$ & $0(0 \%)$ & \\
& Sesudah intervensi 1 pagi (hari 1) & $9(90 \%)$ & $1(10 \%)$ & \\
2 & Sebelum intervensi 2 sore (hari 1) & $10(100 \%)$ & $0(0 \%)$ & \\
& Sesudah intervensi 2 sore (hari 1) & $9(90 \%)$ & $1(10 \%)$ & \multirow{2}{*}{$0,000^{*}$} \\
& Sebelum intervensi 1 pagi (hari 2) & $10(100 \%)$ & $0(0 \%)$ & \\
& Sesudah intervensi 1 pagi (hari 2) & $4(40 \%)$ & $6(60 \%)$ & \\
& Sebelum intervensi 2 sore (hari 2) & $3(30 \%)$ & $7(70 \%)$ & \\
& Sesudah intervensi 2 sore (hari 2) & $1(10 \%)$ & $9(90 \%)$ & \\
\hline
\end{tabular}

Ket: * Uji Cochran

Tabel 3 Analisis Efektifitas Fisiotherapi Dada terhadap Bersihan Jalan Nafas antara Fisioterapi Dada Pre 1 dengan Post 2, 4, 6 dan 8 pada Anak Balita dengan Pneumonia

\begin{tabular}{llccc}
\hline \multirow{2}{*}{ No } & \multicolumn{1}{c}{ Pengukuran } & \multicolumn{2}{c}{ Bersihan Jalan Napas } & $\begin{array}{c}\text { P } \\
\text { Value }\end{array}$ \\
\cline { 2 - 3 } & \multicolumn{1}{c}{ Tdk Bersih } & Bersih & Pengukuran sebelum intervensi hari pertama dan \\
2 & $\begin{array}{l}\text { sesudah intervensi hari pertama (pagi) } \\
\text { Pengukuran pagi hari sebelum intervensi hari } \\
\text { pertama dan sesudah intervensi hari pertama } \\
\text { (sore) }\end{array}$ & $9(90 \%)$ & $1(10 \%)$ & $1,000^{*}$ \\
3 & $\begin{array}{l}\text { Pengukuran pagi hari sebelum intervensi dan } \\
\text { sesudah intervensi hari kedua (pagi) }\end{array}$ & $4(40 \%)$ & $6(60 \%)$ & $0,031^{*}$ \\
4 & $\begin{array}{l}\text { Pengukuran pagi hari sebelum intervensi dan } \\
\text { sesudah intervensi hari kedua (sore) }\end{array}$ & $1(10 \%)$ & $9(90 \%)$ & $0,004^{*}$ \\
\hline
\end{tabular}

Ket: * Uji Mc Nemar

2) Pursed Lips Breathing

Tabel 4 Analisis Efektifitas PLB terhadap Bersihan Jalan Nafas pada Anak Balita dengan Pneumonia

\begin{tabular}{ccccc}
\hline & Pengukuran Bersihan & \multicolumn{2}{c}{ Bersihan Jalan Nafas } & \\
\cline { 3 - 4 } N & $\begin{array}{c}\text { Jalan Nafas pada } \\
\text { kelompok yang diberi } \\
\text { PLB }\end{array}$ & $\begin{array}{c}\text { Tdk } \\
\text { Bersih }\end{array}$ & Bersih & \\
& P Value \\
\hline 1 & Sebelum intervensi (hari 1) & $10(100 \%)$ & $0(0,0)$ & \\
2 & Sesudah intervensi (hari 1) & $10(100 \%)$ & $0(0,0)$ & $0,112^{*}$ \\
3 & Sebelum intervensi (hari 2) & $8(80 \%)$ & $2(20 \%)$ & \\
4 & Sesudah intervensi (hari 2) & $8(80 \%)$ & $2(20 \%)$ & \\
\hline
\end{tabular}

Ket: * Uji Cochran

Tabel 5 Analisis Efektifitas PLB terhadap Bersihan Jalan Nafas antara PLB Pre 1 dengan Post 2 dan 4 pada Anak Balita dengan Pneumonia

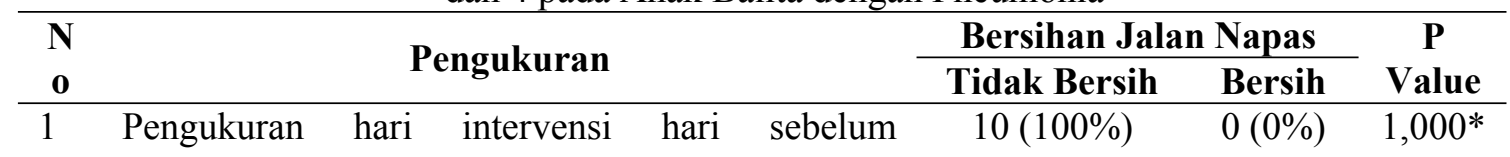




\begin{tabular}{|c|c|c|c|c|}
\hline \multirow{2}{*}{$\begin{array}{l}\mathbf{N} \\
\mathbf{0}\end{array}$} & \multirow{2}{*}{ Pengukuran } & \multicolumn{2}{|c|}{ Bersihan Jalan Napas } & \multirow{2}{*}{$\begin{array}{c}P \\
\text { Value }\end{array}$} \\
\hline & & Tidak Bersih & Bersih & \\
\hline & $\begin{array}{l}\text { intervensi hari pertama dan sesudah intervensi } \\
\text { hari pertama }\end{array}$ & & & \\
\hline 2 & $\begin{array}{l}\text { Pengukuran hari sebelum intervensi hari pertama } \\
\text { dan sesudah kedua }\end{array}$ & $8(80 \%)$ & $2(20 \%)$ & $0,500^{*}$ \\
\hline
\end{tabular}

\section{Fisioterapi Dada dan PLB}

Tabel 6 Analisis Efektifitas Fisiotherapi Dada dan PLB Terhadap Bersihan Jalan Nafas pada Anak Balita dengan Pneumonia

\begin{tabular}{ccccc}
\hline \multirow{2}{*}{ N } & Pengukuran Bersihan Jalan Nafas & \multicolumn{2}{c}{ Bersihan Jalan Nafas } & \multirow{2}{*}{ P } \\
\cline { 3 - 3 } o & $\begin{array}{c}\text { pada kelompok yang diberi } \\
\text { Fisiotherapi Dada \& PLB }\end{array}$ & Tdk Bersih & Bersih & Value \\
\hline 1 & Sebelum intervensi 1 pagi (hari 1) & $10(10 \%)$ & $0(0 \%)$ & \\
2 & Sesudah intervensi 1 pagi (hari 1) & $8(80 \%)$ & $2(20 \%)$ & \\
3 & Sebelum intervensi 2 sore (hari 1) & $10(100 \%)$ & $0(0 \%)$ & \\
4 & Sesudah intervensi 2 sore (hari 1) & $7(70 \%)$ & $3(30 \%)$ & \multirow{2}{*}{$0,000^{*}$} \\
5 & Sebelum intervensi 1 pagi (hari 2) & $7(70 \%)$ & $3(30 \%)$ & \\
6 & Sesudah intervensi 1 pagi (hari 2) & $3(30 \%)$ & $7(70 \%)$ & \\
7 & Sebelum intervensi 2 sore (hari 2) & $2(20 \%)$ & $8(80 \%)$ & \\
8 & Sesudah intervensi 2 sore (hari 2) & $0(0 \%)$ & $10(100 \%)$ & \\
Ket: * Uji Cochran & &
\end{tabular}

Tabel 7 Analisis Efektifitas Fisiotherapi Dada dan Pursed Lips Breathing terhadap Bersihan Jalan Nafas antara Fisiotherapi Dada dan Pursed Lips Breathing Pre 1 dengan Post 2, 4, 6 dan 8 pada Anak Balita dengan Pneumonia

\begin{tabular}{|c|c|c|c|c|}
\hline \multirow{2}{*}{ No } & \multirow{2}{*}{ Pengukuran } & \multicolumn{2}{|c|}{ Bersihan Jalan Napas } & \multirow{2}{*}{$\begin{array}{c}P \\
\text { Value }\end{array}$} \\
\hline & & Tidak Bersih & Bersih & \\
\hline 1 & $\begin{array}{l}\text { Pengukuran pagi hari sebelum intervensi hari } \\
\text { pertama dan sesudah intervensi hari pertama pagi }\end{array}$ & $8(80 \%)$ & $2(20 \%)$ & 0,500 \\
\hline 2 & $\begin{array}{l}\text { Pengukuran pagi hari sebelum intervensi hari } \\
\text { pertama dan sesudah intervensi hari pertama sore }\end{array}$ & $7(70 \%)$ & $3(30 \%)$ & 0.250 \\
\hline 3 & $\begin{array}{l}\text { Pengukuran pagi hari sebelum intervensi hari } \\
\text { kedua dan sesudah intervensi hari kedua pagi }\end{array}$ & $3(30 \%)$ & $7(70 \%)$ & 0,016 \\
\hline 4 & $\begin{array}{l}\text { Pengukuran pagi hari sebelum intervensi hari } \\
\text { kedua dan sesudah intervensi hari kedua sore }\end{array}$ & $0(0 \%)$ & $10(100 \%)$ & 0,002 \\
\hline
\end{tabular}

Ket: * Uji Mc Nemar

\section{PEMBAHASAN}

\section{Karakteristik Responden}

Rata-rata usia anak pada kelompok fisioterapi dada adalah 2.50 tahun dengan usia termuda adalah 1 tahun dan usia tertua 5 tahun. Untuk kelompok PLB rata-rata usia anak adalah 2.60 tahun dengan usia termuda 1 tahun dan usia tertua 4 tahun. Sedangan untuk kelompok fisioterapi dada dan PLB rata-rata 2.60 tahun dengan usia termuda 1 tahun dan usia tertua 4 tahun.

Penelitian ini didukung oleh Hartati (2011) yang mengatakan bahwa insiden tertinggi terkena pneumonia adalah usia $>12$ bulan $-<60$ bulan. Bayi dan balita memiliki mekanisme pertahanan yang masih lemah dibanding orang dewasa, sehingga balita termasuk ke dalam kelompok rawan terhadap infeksi influenza dan pneumonia. Anak yang berusia 0-24 bulan lebih rentan terhadap penyakit pneumonia dibandingkan anak-anak yang berusia diatas 2 tahun. Hal ini disebabkan oleh imunitas yang belum sempurna dan saluran pernapasan yang relatif sempit, sehingga bayi dan balita mudah sekali terkena penyakit pneumonia (Depkes RI, 2004). 


\section{Analisa Pengaruh Bersihan Jalan Nafas Sebelum dan Sesudah Pemberian Intervensi Fisioterapi Dada}

Hasil uji statistik dengan menggunakan uji Cochran didapatkan bahwa nilai Pvalue $<$ a yang artinya ada perbedaan yang bermakna antara bersihan jalan nafas antara sebelum dan sesudah dilakukan intervensi fisioterapi dada pada anak balita dengan pneumonia. Dari hasil penelitian didapatkan bahwa pada intervensi pertama belum terjadi perubahan terhadap bersihan jalan napas, tetapi pada intervensi berikutnya terjadi perubahan terhadap bersihan jalan napas dan perubahan yang sangat signikan terjadi pada intervensi kedua (sore hari) hari kedua. Semakin lama intervensi yang dilakukan maka akan semakin terlihat perubahan terhadap bersihan jalan napas balita.

Hasil penelitian ini membuktikan bahwa fisioterapi dada berpengaruh terhadap bersihan jalan nafas antara sebelum dan sesudah dilakukan intervensi pada balita dengan pneumonia. Fisioterapi dada mencakup 3 teknik yaitu postural drainage, perkusi dada dan vibrasi (Asih dan Efendy, 2004). Metode ini dapat digunakan secara berurutan pada posisi drainage yang berbeda dan harus diawali dengan bronchodilator (jika diprogramkan), dan dilanjutkan dengan nafas dalam dan batuk (Smeltzer \& Bare, 2002).

Fisioterapi dada sangat berguna bagi penderita penyakit respirasi baik yang bersifat akut maupun kronis. Fisioterapi dada adalah salah satu fisioterapi yang menggunakan teknik postural drainage, perkusi dada dan vibrasi. Secara fisiologis Perkusi pada permukaan dinding akan mengirimkan gelombang berbagai amplitude dan frekuensi sehingga dapat mengubah konsistensi dan lokasi sekret (Potter \& Perry, 2005). Menurut Smeltzer \& Bare (2002) vibrasi yang dilakukan setelah perkusi meningkatkan turbulensi udara ekspirasi sehingga dapat melepaskan mukus kental yang melekat pada bronkhus dan bronkiolus, sehingga postural drainage merupakan salah satu intervensi untuk melepaskan sekresi dai berbagai segmen paru - paru dengan menggunakan pengaruh gaya gravitasi. Postural drainage menggunakan posisi khusus yang meningkatkan gaya gravitasi membantu mengeluarkan sekresi bronkhial.
Penelitian lain yang dilakukan oleh Hussein (2011) di Cairo University yang bertujuan untuk mengetahui efek fisioterapi dada terhadap bersihan jalan napas anak yang mengalami pneumonia. Penelitian dilakukan pada dua kelompok yaitu kelompok kontrol (30 responden) dan kelompok intervensi (30 responden). Hasil penelitian didapatkan bahwa fisioterapi dada efekif dalam meningkatkan bersihan saluran udara dengan anak yang mengalami pneumonia yang dievaluasi dari penurunan kebutuhan oksigen dan frekuensi penyedotan (suction), hasil uji statistik penelitian ini menunjukkan ada perbedaan bermakna degan $\mathrm{P}=0,000$.

Pada usia anak semua organ tubuh terus berkembang sampai mencapai fungsi yang sempurna, termasuk sistem pernapasan dan sistem kardiovaskuler yang mempunyai peranan penting dalam pengaturan status oksigenasi. Alveoli berkembang baik ukuran, bentuk maupun jumlahnya sehingga saluran pernapasan menjadi sempurna, hal ini dapat dicapai pada anak usia 12 tahun. Permukaan alveolar yang bertambah luas berguna untuk pertukaran gas. Pertumbuhan anak berhubunga erat dengan peningkatan percabangan dari bronkiolus perifer dan jumlah alveoli. Semakin anak bertambah tinggi, maka semakin besar dan luas permukaan paru-paru. Pada balita yang mengalami gangguan bersihan jalan napas terjadi penumpukan sekret, sekret akan lepas dari saluran pernapasan dan akhirnya dapat keluar melalui mulut dengan adanya proses batuk pada saat dilakukan fisioterapi dada. Menurut Lubis (2005), fisioterapi dada sangat efektif dalam mengeluarkan sekret dan memperbaiki ventilasi pada pasien dengan fungsi paru yang terganggu. Tujuan pokok fisioterapi dada pada penyakit paru adalah mengembalikan dan memelihara fungsi otototot pernapasan dan membantu membersihkan sekret dari bronkhus dan mencegah penumpukan sekret.

\section{Analisa Pengaruh Bersihan Jalan Napas Sebelum dan Sesuda eberian Intervensi PLB}

Hasil uji statistik dengan menggunakan uji Cochran didapatkan bahwa nilai Pvalue $>$ a yang artinya tidak ada perbedaan yang bermakna antara bersihan jalan nafas antara sebelum dan sesudah 
dilakukan intervensi pursed lips breathing pada anak balita dengan pneumonia di RSUD Kabupaten Indramayu.

Ketidaefektifan dalam penelitian ini kemungkinan dikarenakan karena usia responden yang masih balita, kadar hemoglobin, suhu tubuh, kekuatan meniup, tingkat dehidrasi, lama sakit. Seperti penelitian yang dilakukan oleh Sutini, $\mathrm{T}$ (2011) tentang pengaruh aktivitas bermain meniup tiupan lidah terhadap status oksigenasi pada anak usia prasekolah dengan pneumonia di RS Islam Jakarta yang didapat hasil bahwa aktivitas bermain meniup "tiupan lidah" berpengaruh terhadap status oksigenasi.

PLB merupakan salah satu teknik termudah dalam mengurangi sesak napas. Teknik ini merupakan cara mudah dalam memperlambat frekuensi napas sehingga napas menjadi lebih efektif. Teknik ini dapat membantu untuk menghasilkan udara yang banyak ke dalam paru dan mengurangi energi yang dikeluarkan saat bernapas. Selain itu juga, dapat meningkatkan tekanan alveolus pada setiap lobus paru sehingga dapat meningkatkan aliran udara saat ekspirasi. Peningkatan aliran udara pada saat ekspirasi akan mengevakuasi sekret keluar dari saluran napas. tindakan ini sebagai salah satu upaya yang diduga mampu meningkatkan oksigenasi (Brunner \& Sudath, 2010) karena memberikan efek yang baik terhadap pernapasan, diantaranya adalah (a) meningkatkan ventilasi, (b) membebaskan udara yang terperangkap dalam paru-paru, (c) menjaga napas tetap terbuka lebih lama dan mengurangi kerja napas, (d) memperpanjang waktu ekshalasi yang kemudian memperlambat frekuensi napas, (e) meningkatkan pola napas dengan mengeluarkan udara "lama" dan memasukkan udara 'baru' ke dalam paru, (f) menghilangkan sesak napas dan (g) meningkat relaksasi.

Menurut Brunner \& Suddarth (2008) inspirasi yang adekuat dapat meningkatkan volume dan tekanan alveoli sehingga dapat meningkatkan tekanan aliran udara saat inspirasi. Peningkatan tekanan aliran udara ekspirasi dapat menggerakan silia-silia saluran napas yang berguna untuk mengeluarkan benda asing yang ada didalamnya, termasuk secret. Semakin kuat meniup semakin kuat pula silia bergerak untuk mendorong benda asing atau secret keluar dari jalan napas sehingga pada akhirnya dapat memberikan dampak positif terhadap perubahan status oksigenasi (Sutini, 2011).

Penelitian lain yang dilakukan oleh Enright, Chatam \& Ionescu (2004) di Australia pada pasien PPOK yang tidak di rawat di rumah sakit, menghasilkan pengingkatan fungsi faal paru rata-rata sebesar $60 \%$ setelah latihan PLB dan latihan otot-otot pernapasan selama 8 minggu, sedangkan pada pasien yang tidak dilakukan teknik ini rata-rata hanya meningkat $10 \%$.

Penelitian lain yang dilakukan oleh Division of Physiotherapi (2003) di rumah sakit Karolinska University Swedia pada tahun 2003 pada pasien PPOK berjumlah 32 pasien yang dirawat di rumah sakit. dihasilkan fungsi faal paru rata-rata $90 \%$ setelah latihan PLB selama 1 minggu.

PLB menimbulkan obstruksi terhadap aliran udara ekshalasi dan meningkatkan tekanan udara, menurunkan gradient tekanan transmural dan mempertahankan kepatenan jalan napas yang kolaps selama ekshalasi. Proses ini membantu menurunkan pengeluaram udara yang terjebak, tidak secara langsung menurunkan kapasitas fungsional residu, tetapi perbaikan sesak napas merupakan akibat restorasi diafragma terhadap posisi thoraks yang mengalami

\section{Analisa Pengaruh Bersihan Jalan Nafas Sebelum dan Sesudah Pemberian Intervensi Fisioterapi Dada dan PLB \\ Hasil uji statistik dengan} menggunakan uji Cochran didapatkan bahwa nilai Pvalue $<$ a yang artinya ada perbedaan yang bermakna antara bersihan jalan nafas antara sebelum dan sesudah dilakukan intervensi fisioterapi dada dan PLB pada anak balita dengan pneumonia di RSUD Kabupaten Indramayu. Dari hasil penelitian didapatkan bahwa pada intervensi pertama belum terjadi perubahan terhadap bersihan jalan napas, tetapi pada intervensi berikutnya terjadi perubahan terhadap bersihan jalan napas dan perubahan yang sangat signifikan terjadi pada intervensi kedua (sore hari) hari kedua yaitu semua responden (10 balita) mengalami perubahan terhadap bersihan jalan napas. Semakin lama intervensi yang dilakukan maka akan semakin terlihat perubahan terhadap bersihan jalan napas balita. Hal ini 
karena pada kelompok ini diberikan 2 intervensi yaitu fisioterapi dada dan PLB.

Perbedaan pada penelitian ini dengan peneltian sebelumnya yaitu pada penelitian ini menggabungkan kedua intervensi yang diberikan yaitu fisioterapi dada dan PLB terhadap bersihan jalan napas pada anak balita dengan pneumonia dan hasilnya sangat terbuki efektif jika dilakukan secara bersamasama untuk bersihan jalan napas pada anak balita dengan pneumonia.

\section{PENUTUP}

\section{Kesimpulan}

Berdasarkan hasil penelitian, maka dapat diambil kesimpulan sebagai berikut :

1. Ada perbedaan antara bersihan jalan napas sebelum dan sesudah dilakukan intervensi fisioterapi dada pada anak balita dengan pneumonia dengan $\mathrm{p}$ Value 0,000

2. Tidak ada perbedaan antara bersihan jalan napas sebelum dan sesudah dilakukan intervensi pursed leps breathing (tiupan lidah) pada anak balita dengan pneumonia dengan $\mathrm{p}$ Value 0,112

3. Ada perbedaan antara bersihan jalan napas sebelum dan sesudah dilakukan intervensi fisioterapi dada dan pursed lips breathing (tiupan lidah) pada anak balita dengan pneumonia dengan $\mathrm{p}$ Value 0,000

\section{DAFTAR PUSTAKA}

Asih, N.G.Y., \& Effendy, C., 2004. Keperawatan Medikal Bedah : Klien dengan Gangguan Pernafasan, Cetakan Pertama. Jakarta : EGC.

Brunner \& Suddarth. 2002. Buku ajar keperawatan medical bedah. (Edisi 8). vol.1. diterjemahkan oleh Ester. Jakarta : EGC.

Brunner \& Suddarth. 2010. Buku ajar keperawatan medical bedah. (Edisi 8). vol.1. diterjemahkan oleh Ester. Jakarta : EGC.

Depkes RI. 2004. Pedoman program pemberantasan penyakit infeksi saluran pernapasan akut (ISPA) untuk penanggulangan pneumonia pada balita. Jakarta : Depkes RI.

Division Of Physioterapi. 2003. Patient information series chronic obtruvtive pulmonary disease (COPD). Karolinska University Hospital, Sweden. Diunduh tanggal 27 Juli 201.

Enright S, Chatam K \& Ionescu AA. 2004. Inspiratory Muscle Training Improves Lung Function and Exercise Capacity in Adults With Cystic Fibrosis. Diunduh 27 Juli 2017

Hartati, S. 2011. Analisis faktor risiko yang berhubungan dengan kejadian pneumonia pada anak balita di RSUD pasar rebo jakata. Jakarta : Tesis.

Herdman. T. Heather. 2015. Nanda international Inc. diagnosis keperawatan: definisi \& klasifikasi 2015 - 2017/editor, T. Heather Herdman, Shigemi Kamitsuru : alih bahasa Keliat B. A., et al. Jakarta : EGC.

Hussein H, A \& Gehan A. E. 2011. Effect of chest physiotherapy on improving chest airways among infant with pneumonia. Department of pediatric nursing, faculty of nursing, cairo university. Diunduh 25 Februari 2017

Kemenkes RI. 2016. Profil Kesehatan Indonesia . Jakarta : Depkes RI

Lubis, H. 2005. Fisioterapi Pada Penyakit Paru Anak, e-USU Respiratory, Universitas Sumatera Utara.

Potter, P.A., \& Perry, A. G. 2005. Buku ajar fundamental keperawatan : konsep, proses \& praktik. (Edisi 4). Alih bahasa Renata, K., et al. Jakarta : EGC

Potter, P.A., \& Perry, A. G. 2009. Fundamental of nursing. (Edisi 7). vol. 3 . Jakarta : Elsevier. 
Pengaruh Pemberian Fisioterapi Dada dan Pursed Lips Breathing (Tiupan Lidah) terhadap Bersihan Jalan Nafas pada Anak Balita Dengan Pneumonia

Smeltzer, S.C., \& Bare, B. G.,. 2002. Buku ajar keperawatan medical bedah Brunner \& Suddarth (Edisi 8). Volume 1 Alih bahasa Waluyo, A et al. Jakarta : EGC.

Sutini, T. 2011. Pengaruh aktivitas bermain meniup tiupan lidah terhadap status oksigenasi pada anak usia prasekolah dengan pneumonia di rumah sakit islam jakatra. Tesis.

WHO. (2009). Global action plan for prevention and control of pneumonia. Diunduh 25 Februari 2017

WHO. 2016. Pneumonia. Diunduh 25 Februari 2017

Wong. D., et al. 2009. Buku ajar keperawatan pediatric. (Edisi 6). Volume 2. Jakarta : EGC 